\title{
Complexity of diatom response to Lateglacial and Holocene climate and environmental change in ancient, deep and oligotrophic Lake Ohrid (Macedonia and Albania)
}

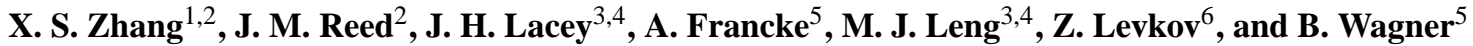 \\ ${ }^{1}$ Institute of Loess Plateau, Shanxi University, Taiyuan, China \\ ${ }^{2}$ Department of Geography, Environment and Earth Sciences, University of Hull, Hull, UK \\ ${ }^{3}$ Centre for Environmental Geochemistry, School of Geography, University of Nottingham, Nottingham, UK \\ ${ }^{4}$ NERC Isotope Geosciences Facilities, British Geological Survey, Nottingham, UK \\ ${ }^{5}$ Institute of Geology and Mineralogy, University of Cologne, Cologne, Germany \\ ${ }^{6}$ Institute of Biology, Faculty of Natural Sciences, Ss. Cyril and Methodius University, Skopje, \\ Republic of Macedonia
}

Correspondence to: X.S. Zhang (zhangxs08@gmail.com)

Received: 30 July 2015 - Published in Biogeosciences Discuss.: 1 September 2015

Revised: 31 January 2016 - Accepted: 18 February 2016 - Published: 3 March 2016

\begin{abstract}
Lake Ohrid (Macedonia and Albania) is a rare example of a deep, ancient Mediterranean lake and is a key site for palaeoclimate research in the northeastern Mediterranean region. This study conducts the analysis of diatoms as a proxy for Lateglacial and Holocene climate and environmental change in Lake Ohrid at a higher resolution than in previous studies. While Lake Ohrid has the potential to be sensitive to water temperature change, the data demonstrate a highly complex diatom response, probably comprising a direct response to temperature-induced lake productivity in some phases and an indirect response to temperaturerelated lake stratification or mixing and epilimnetic nutrient availability in others. The data also demonstrate the possible influence of physical limnological (e.g. the influence of wind stress on stratification or mixing) and chemical processes (e.g. the influence of catchment dynamics on nutrient input) in mediating the complex response of diatoms. During the Lateglacial (ca. 12 300-11 800 cal yr BP), the low-diversity dominance of hypolimnetic Cyclotella fottii indicates low lake productivity, linked to low water temperature. Although the subsequent slight increase in small, epilimnetic $C$. minuscula during the earliest Holocene (ca. $11800-10600$ cal yr BP) suggests climate warming and enhanced stratification, diatom concentration remains as low as during the Lateglacial, suggesting that water tempera-
\end{abstract}

ture increase was muted across this major transition. The early Holocene (ca. 10 600-8200 cal yr BP) is characterised by a sustained increase in epilimnetic taxa, with mesotrophic C. ocellata indicating high water-temperature-induced productivity between ca. 10600-10200 cal yr BP and between ca. 9500-8200 cal yr BP and with C. minuscula in response to low nutrient availability in the epilimnion between ca. 10200-9500 cal yr BP. During the middle Holocene (ca. 8200-2600 cal yr BP), when sedimentological and geochemical proxies provide evidence for maximum Holocene water temperature, anomalously low $C$. ocellata abundance is probably a response to epilimnetic nutrient limitation, almost mimicking the Lateglacial flora apart from the occurrence of mesotrophic Stephanodiscus transylvanicus in the hypolimnion. During the late Holocene (ca. 2600 cal yr BPpresent), high abundance and fluctuating composition of epilimnetic taxa are probably a response more to enhanced anthropogenic nutrient input, particularly nitrogen enrichment, than to climate. Overall, the data indicate that previous assumptions concerning the linearity of diatom response in this deep, ancient lake are invalid, and multi-proxy analysis is essential to improve understanding of palaeolimnological dynamics in future research on the long, Quaternary sequence. 


\section{Introduction}

Deep, ancient lakes are of global importance for palaeoclimate research, and diatom records from these lakes can provide powerful insights into mechanisms of climate and environmental change over long timescales (Mackay et al., 2010). Lake Ohrid (Macedonia and Albania) is a rare example of a deep, ancient Mediterranean lake (Roberts and Reed, 2009). It is thought to be the oldest lake in Europe, and probably the most biodiverse lake in the world (Albrecht and Wilke, 2008; Levkov and Williams, 2012). It is therefore a key site for palaeoclimate research in the northeastern Mediterranean region (Wagner et al., 2014). As most Mediterranean lakes are relatively shallow and demonstrate a strong diatom response to shifts in moisture availability (Zhang et al., 2014), the diatom record in Lake Ohrid may provide an important means by which to disentangle temperature and precipitation effects in Mediterranean climate research.

Temperature reconstructions during the Lateglacial and Holocene in the northeastern Mediterranean region are rare and rely mainly on pollen data (e.g. Bordon et al., 2009; Dormoy et al., 2009; Pross et al., 2009). Using pollen as a temperature proxy in this region is controversial. Renssen et al. (2012) suggested that pollen-based temperature reconstruction may be unreliable since precipitation rather than temperature is the main climatic control on Mediterranean vegetation distribution, while Mauri et al. (2015) argued instead that pollen transfer functions can provide robust results for temperature reconstruction in this region. Quantitative climate reconstruction methods have their own strengths and weaknesses (Birks et al., 2010; Juggins and Birks, 2012), and pollen-based temperature reconstructions can show different patterns and amplitudes of change depending on the technique used (Dormoy et al., 2009; Peyron et al., 2013). Deep Lake Ohrid, for which no major lake-level change during the Lateglacial and Holocene has been reported (Wagner et al., 2009; Reed et al., 2010), is arguably an ideal site for using palaeolimnological proxies such as diatoms to improve understanding of temperature change in this region.

To date, diatom-based palaeoclimate research in Lake Ohrid has focused on low-resolution analysis of response to the last glacial-interglacial cycle (Wagner et al., 2009; Reed et al., 2010; Cvetkoska et al., 2012, 2015). Fluctuations in diatom composition between glacial or stadial and interglacial or interstadial stages have suggested a strong and simple response to temperature-induced changes in lake productivity. Here, we focus on the analysis of diatom response to Lateglacial and Holocene limnological, climate and environmental change, testing the response of diatoms in greater detail than has been achieved previously. Core Co1262, in the western part of the lake, is chronologically well constrained and is the longest and most continuous Holocene sequence yet retrieved from the lake. Diatom results are compared with sedimentological and geochemical data from the same core (Wagner et al., 2012; Lacey et al., 2015). We also compare core Co1262 diatom results with low-resolution diatom data from core Lz1120 (southeastern Lake Ohrid; Wagner et al., 2009), core Co1202 (northeastern Lake Ohrid; Reed et al., 2010; Cvetkoska et al., 2012), the DEEP site (central Lake Ohrid; Cvetkoska et al., 2015) and core 9 (north-central Lake Ohrid; Roelofs and Kilham, 1983) and with palynological data from the region (Wagner et al., 2009; Panagiotopoulos et al., 2013).

\section{Site description}

Lake Ohrid $\left(40^{\circ} 54^{\prime}-41^{\circ} 10^{\prime} \mathrm{N}, 20^{\circ} 38^{\prime}-20^{\circ} 48^{\prime}\right.$ E; $693 \mathrm{~m}$ a.s.l.; Fig. 1) is an ancient graben lake with a continuous $>1.2 \mathrm{Myr}$ sedimentary record (Wagner et al., 2014; Francke et al., 2016). The lake is about $30 \mathrm{~km}$ long, $15 \mathrm{~km}$ wide, and has a surface area of $358 \mathrm{~km}^{2}$ and a maximum water depth of $293 \mathrm{~m}$ (Albrecht and Wilke, 2008; Wagner et al., 2012). The lake basin has a relatively simple tub-shaped morphometry with steep slopes along the western and eastern sides and less inclined shelves in the northern and southern parts. It is surrounded by the Galičica Mountain ( $2256 \mathrm{~m}$ a.s.l.) to the east, the Mali i Thatë Mountain (2276 ma.s.l.) to the southeast, the Jablanica Mountain (2225 m a.s.1.) to the northwest, and the Mokra Mountain (1512 ma.s.l.) to the west. Geological formations around the lake comprise Palaeozoic metamorphics to the northeast, karstified Triassic limestones to the east, southeast and northwest, Jurassic ophiolites to the west, Tertiary molasse deposits to the southwest and south, and Quaternary fluviolacustrine deposits in the Struga, Ohrid and Starovo plains to the north, northeast and south, respectively (Hoffmann et al., 2010; Reicherter et al., 2011). The local climate belongs to the Mediterranean regime with minimum precipitation occurring in June-August, and it is also influenced by the continental regime as it is surrounded by high mountains (Watzin et al., 2002). North-south winds prevail in the lake basin (Stanković, 1960; Matzinger et al., 2006a). The catchment vegetation is distributed mainly in altitudinal belts as, in ascending order, mixed deciduous oak forest, beech forest, coniferous forest, and subalpine and alpine meadows (Lézine et al., 2010; Panagiotopoulos et al., 2013).

Lake Ohrid is fed mainly by karstic springs (53\%, comprising $27 \%$ surface springs and $26 \%$ sublacustrine springs), with $24 \%$ of water input from river inflow and $23 \%$ from direct precipitation on the lake surface. Direct outflow is via the Crni Drim River (66\%), with $34 \%$ evaporative loss (Matzinger et al., 2006a). The largest surface springs are those of Sveti Naum and Tushemisht at the southeastern edge of the lake, with smaller complexes comprising the Biljana spring in the northeastern part and the Dobrá Voda spring in the northwest (Albrecht and Wilke, 2008). Sublacustrine springs are located mainly on the eastern shore of the lake, with one in the northwestern corner (Matter et al., 2010). An important source of karstic springs is the Lake Prespa underground outflow, which provides $21 \%$ of total Lake Ohrid 


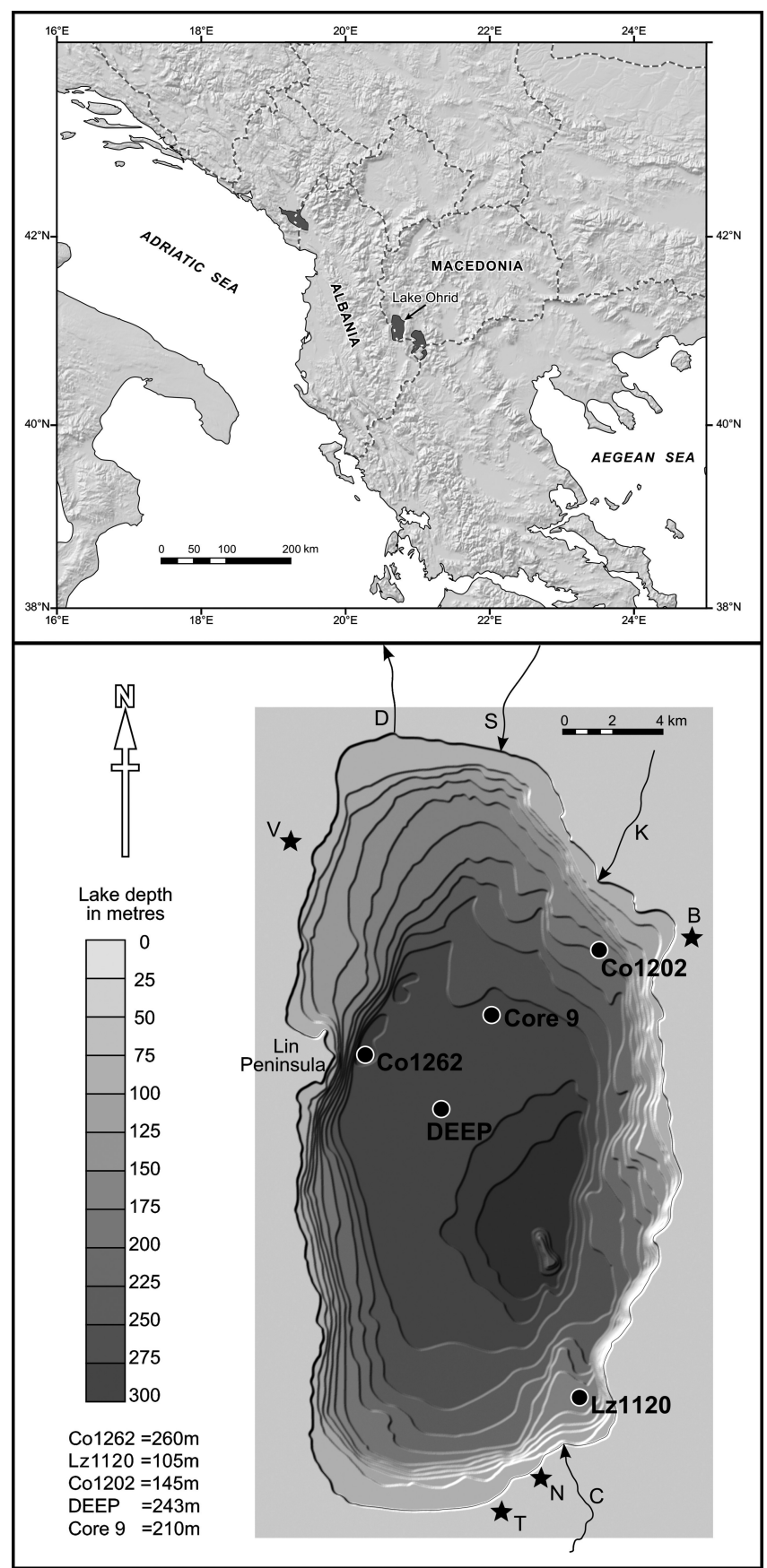

Figure 1. Map showing the location of Lake Ohrid (Macedonia and Albania) and the coring sites Co1262 (this study; Wagner et al., 2012; Lacey et al., 2015), Lz1120 (Wagner et al., 2009), Co1202 (Vogel et al., 2010; Reed et al., 2010; Cvetkoska et al., 2012), DEEP site (Wagner et al., 2014; Francke et al., 2015; Cvetkoska et al., 2015) and Core 9 (Roelofs and Kilham, 1983). Arrows indicate main river flows (C: Cerava River; K: Koselska River; S: Sateska River; D: Crni Drim River), and asterisks indicate major springs (N: Sveti Naum; T: Tushemisht; B: Biljana; V: Dobrá Voda). Modified from Reed et al. (2010). water input (Matzinger et al., 2006b). The karst aquifers are also charged by the infiltration of precipitation on the Galičica and Mali i Thatë mountains. There is no major inflow close to the Lin Peninsula in the western part of the lake. The top $150-200 \mathrm{~m}$ of the water column is mixed every winter, and a complete circulation of the entire water column occurs roughly every seventh winter (i.e. it is oligomictic; Stanković, 1960; Matzinger et al., 2006a). Lake Ohrid is alkaline, with pelagic water $\mathrm{pH} 8.0-8.9$ (measured in 20042006; Tasevska et al., 2012) and ionic composition dominated by bicarbonate and calcium (Stanković, 1960). It is highly oligotrophic, with total phosphorus and total nitrogen concentration throughout the water column at the lake centre of 4.6-6.8 and $171-512 \mu \mathrm{g} \mathrm{L}{ }^{-1}$, respectively (measured in 2000-2001; Watzin et al., 2002) and low dissolved silica concentration of $<0.2 \mathrm{mg} \mathrm{L}^{-1}$ in the trophogenic zone in summer (in 1957; Stanković, 1960). It is typically fresh and clear, with low water conductivity of $195-239 \mu \mathrm{S} \mathrm{cm}^{-1}$ in the littoral zone (in 2009-2010; Schneider et al., 2014) and a high Secchi depth of 11-21 m (in 2000-2003; Petrova et al., 2008).

\section{Material and methods}

Following detailed hydro-acoustic surveys carried out between 2004 and 2009 on lake bathymetry and sediment architecture (Wagner et al., 2012; Lindhorst et al., 2015), a $1008 \mathrm{~cm}$ long core, Co1262, was recovered in June 2011 from $260 \mathrm{~m}$ water depth off the Lin Peninsula at the western margin of Lake Ohrid, using UWITEC gravity and piston coring equipment from a floating platform (www.uwitec.at). Excluding a $200 \mathrm{~cm}$ thick mass wasting deposit and three smaller ones $(<20 \mathrm{~cm})$ identified by coarse grain size and low water content (Wagner et al., 2012), the undisturbed composite sediment sequence is $785 \mathrm{~cm}$ long.

The age model of core Co1262 was described in detail by Lacey et al. (2015). Radiocarbon dating, tephrostratigraphy and cross correlation of calcite and organic matter content with other sediment cores from Lake Ohrid and the hydraulically linked adjacent Lake Prespa were used to provide a chronological control for core Co1262. The age model was calculated based on five calendar ages of terrestrial plant remains, three well-dated tephras (Somma-Vesuvius AD 472/512 tephra, Mount Etna FL tephra and SommaVesuvius Mercato tephra; Sulpizio et al., 2010; Damaschke et al., 2013) and five correlation points, using the smoothing spline method (smoothing: 0.1) with the software package Clam 2.2 (Blaauw, 2010). One radiocarbon age of fish remains is apparently too old and was excluded, as the fish remains are probably affected by a reservoir effect or they are redeposited (Wagner et al., 2012). The radiocarbon and tephra chronologies are shown in Table 1, and the correlation of core Co1262 with other sediment cores was described in detail by Wagner et al. (2012). The age model shows that 


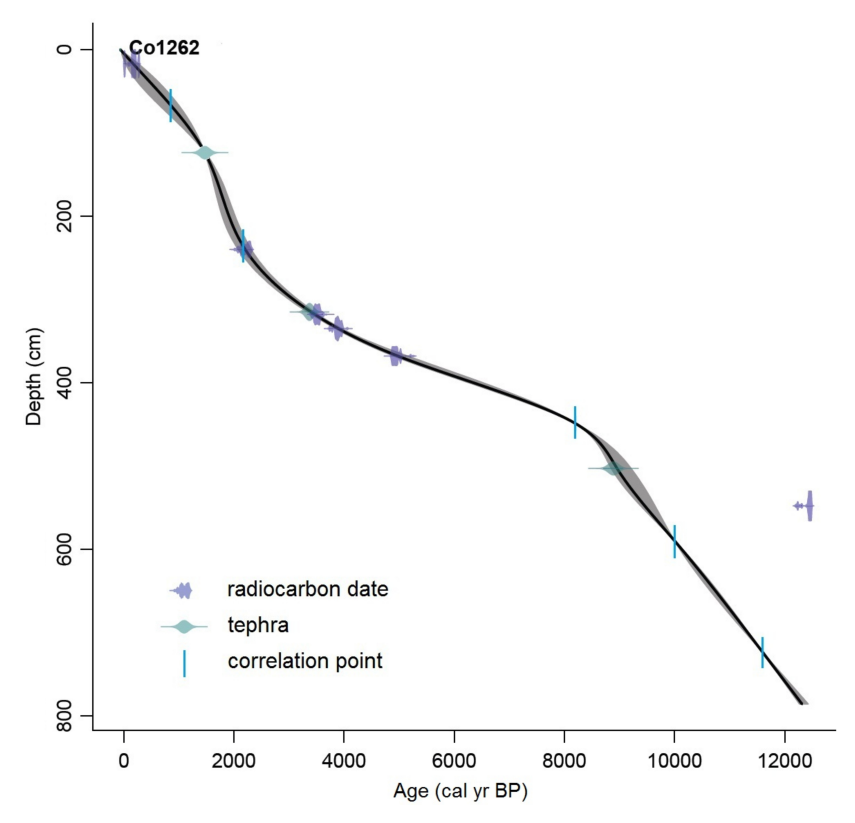

Figure 2. Age-depth model of core Co1262 (modified from Lacey et al., 2015).

core Co1262 covers the past 12300 years (Fig. 2), spanning the Lateglacial and Holocene period.

Diatom analysis was carried out on 104 samples in the $785 \mathrm{~cm}$ long master sequence, taken every $8 \mathrm{~cm}$ but at a higher resolution of $4 \mathrm{~cm}$ around putative abrupt events at ca. 8200 and $4200 \mathrm{cal} \mathrm{yr} \mathrm{BP.} \mathrm{The} \mathrm{age} \mathrm{resolution} \mathrm{is} \mathrm{ca.} 80$ 110 years for the top $120 \mathrm{~cm}$, ca. 40-70 years between $240-120 \mathrm{~cm}$ (ca. $2200-1400$ cal yr BP), ca. 100-200 years between $350-240 \mathrm{~cm}$ (ca. 4400-2200 cal yr BP), ca. 270350 years between $435-350 \mathrm{~cm}$ (ca. $7800-4400 \mathrm{cal} \mathrm{yr} \mathrm{BP}$ ) and ca. 90-120 years for the lower sequence. The relatively low age resolution in the middle of the core is a result of low sedimentation rate.

Standard techniques in Battarbee et al. (2001) were adopted for preparation of diatom slides. Approximately $0.1 \mathrm{~g}$ dry weight sediment samples were heated in $25-30 \mathrm{~mL}$ $30 \% \mathrm{H}_{2} \mathrm{O}_{2}$ to oxidise organic matter, and a few drops of concentrated $\mathrm{HCl}$ were added to remove carbonates and remaining $\mathrm{H}_{2} \mathrm{O}_{2}$. The residue was suspended in distilled water, centrifuged and washed four to five times to remove clay and remaining $\mathrm{HCl}$. The suspension was diluted to an appropriate concentration, and known quantities of plastic microspheres were added to allow calculation of absolute diatom concentration. Diatom slides were mounted using Naphrax ${ }^{\mathrm{TM}}$. Diatoms were counted along transects at $\times 1000$ magnification under oil immersion on an OLYMPUS BX51 light microscope. More than 500 valves per slide were counted. Diatom identification was based on a range of standard literature (Krammer and Lange-Bertalot, 1986, 1988, 1991a, b; Lange-Bertalot, 2001; Krammer, 2002; Houk et al., 2010, 2014) and the dedicated Lake Ohrid works, which reflect on- going revision and improvement of diatom taxonomy (Levkov et al., 2007; Levkov and Williams, 2011; Cvetkoska et al., 2012, 2014a), adopting the nomenclature of the Catalogue of Diatom Names (on-line version; Fourtanier and Kociolek, 2011). The endemics, Cyclotella fottii Hustedt and the smaller taxon Cyclotella hustedtii Jurilj were previously separated (Hustedt, 1945; Jurilj, 1954). They are now combined as $C$. fottii but we split morphotypes into size classes to investigate additional subspecies response (cf. Reed et al., 2010; Cvetkoska et al., 2012). Cyclotella minuscula (Jurilj) Cvetkoska is a new species identification (Cvetkoska et al., 2014a), which was previously identified as Discostella stelligera (Cleve \& Grunow) Houk \& Klee (Roelofs and Kilham, 1983; Wagner et al., 2009) or briefly combined with Cyclotella ocellata Pantocsek (Reed et al., 2010; Cvetkoska et al., 2012). Cyclotella ocellata morphotypes were split according to number of ocelli. Stephanodiscus transylvanicus Pantocsek is another improvement of species identification (Cvetkoska et al., 2012), which was previously identified as Stephanodiscus astraea (Ehrenberg) Grunow (Roelofs and Kilham, 1983), Stephanodiscus neoastraea Håkansson \& Hickel (Wagner et al., 2009) or Stephanodiscus galileensis Håkansson \& Ehrlich (Reed et al., 2010). Diatom results were displayed using Tilia version 1.7.16, and zone boundaries were defined based on relative abundance data according to constrained incremental sum of squares (CONISS) cluster analysis (Grimm, 2011).

To assess the quality of diatom preservation, the $F$ (fractional) index of Ryves et al. (2001) was used to calculate the dissolution of the dominant endemic taxon $C$. fottii which consists of a range of morphotype cell sizes. The $F$ index is the ratio of pristine valves to all valves (sum of pristine and partially dissolved valves), where $F=1$ indicates perfect preservation (Ryves et al., 2001). Unconstrained ordination techniques were used to explore the variance in the diatom relative abundance data using Canoco for Windows 4.5 (Ter Braak and Šmilauer, 2002). Detrended correspondence analysis (DCA) gave the largest gradient length of $1.85 \mathrm{SD}$ units, and thus the linear ordination method principal components analysis (PCA) was selected (Ter Braak, 1995; Lepš and Šmilauer, 2003). Diatom concentration data can be influenced both by differences in cell sizes of diatom species and by changes in sedimentation rates, and diatom biovolume accumulation rate (BVAR) data provide a more robust interpretive tool for productivity than concentration data (Battarbee et al., 2001; Rioual and Mackay, 2005). However, the necessary diatom cell biovolume data and dry sediment bulk density data were not available. Instead, we assessed qualitatively the potential influence of sedimentation rates and valve sizes of main planktonic taxa (including size classes of C. fottii) on diatom concentration. 
Table 1. Age estimates for core Co1262. The calibration of radiocarbon ages into calendar ages is based on Calib 7.0.2 (Stuiver and Reimer, 1993 ) and IntCal13 (Reimer et al., 2013) and on a $2 \sigma$ uncertainty.

\begin{tabular}{|c|c|c|c|c|}
\hline $\begin{array}{l}\text { Core depth } \\
(\mathrm{cm})\end{array}$ & Lab code & Material & $\begin{array}{r}\text { Radiocarbon age } \\
\left({ }^{14} \mathrm{C} \text { yr BP }\right)\end{array}$ & $\begin{array}{r}\text { Calendar age } \\
\text { (cal yr BP) }\end{array}$ \\
\hline 17 & COL 1251.1.1 & terrestrial plant remains & $164 \pm 20$ & $140 \pm 145$ \\
\hline 122 & & the AD 472/512 tephra & & $1478 / 1438$ \\
\hline 240 & COL 1735.1.1 & terrestrial plant remains & $2176 \pm 46$ & $2190 \pm 140$ \\
\hline 315 & & the FL tephra & & $3370 \pm 70$ \\
\hline 318 & COL 1736.1.1 & terrestrial plant remains & $3280 \pm 45$ & $3510 \pm 110$ \\
\hline 335 & COL 1737.1.1 & terrestrial plant remains & $3581 \pm 40$ & $3850 \pm 130$ \\
\hline 368 & COL 1738.1.1 & terrestrial plant remains & $4370 \pm 44$ & $5030 \pm 190$ \\
\hline 503 & & the Mercato tephra & & $8890 \pm 90$ \\
\hline 548 & COL 1243.1.1 & fish remains & $10492 \pm 37$ & $\begin{array}{r}12400 \pm 190 \\
\text { (rejected) }\end{array}$ \\
\hline
\end{tabular}

\section{Results}

A total of 99 diatom species was identified, consisting of 9 planktonic species, 5 facultative planktonic species and 85 benthic species. In spite of low diversity of plankton, its relative abundance is $>90 \%$ throughout the record. Six major diatom assemblage zones can be defined based on diatom relative abundance data, which match well with changes in absolute diatom concentration (Fig. 3). $F$ index values for the endemic Cyclotella fottii are $>0.75$ throughout the record, with $>500$ valves counted on each slide and $>2 \times 10^{7}$ valves $\mathrm{g}^{-1}$ concentration per sample, and diatom preservation quality is high.

In Zone D-1 (785-639 cm; ca. 12 300-10 600 cal yr BP), planktonic C. fottii is dominant at $>80 \%$ abundance, diatom PCA Axis 1 scores are low, and diatom concentration is very low. In Subzone D-1a (785-743 cm; ca. 12300 11800 cal yr BP), facultative planktonic taxa, mainly comprising Staurosirella pinnata (Ehrenberg) Williams \& Round and Pseudostaurosira brevistriata (Grunow) Williams \& Round, are present at ca. $8 \%$ abundance. Subzone D-1b (743-639 cm; ca. $11800-10600 \mathrm{cal} \mathrm{yr} \mathrm{BP)} \mathrm{is} \mathrm{marked} \mathrm{by} \mathrm{a}$ slight increase in the abundance of planktonic C. minuscula, and facultative planktonic taxa decrease slightly to $<5 \%$.

Zone D-2 (639-551 cm; ca. 10 600-9500 cal yr BP) shows a decline in the abundance of $C$. fottii (and its large morphotypes in particular) and a shift to relatively high diatom PCA Axis 1 scores. Cyclotella ocellata increases to ca. 10-30\% in Subzone D-2a (639-607 cm; ca. 10 600-10 200 cal yr BP), and Stephanodiscus transylvanicus appears, with a peak in diatom concentration. In Subzone D-2b $(607-551 \mathrm{~cm}$; ca. $10200-9500$ cal yr BP), C. minuscula increases to ca. 20$40 \%$ at the expense of $C$. ocellata and $S$. transylvanicus, while diatom concentration is relatively low.

In Zone D-3 (551-449 cm; ca. 9500-8200 cal yr BP), C. ocellata is abundant throughout (ca. 20-60\%), with high diatom PCA Axis 1 scores and diatom concentration. In Subzone D-3a (551-511 cm; ca. 9500-9000 cal yr BP), C. ocel- lata shows sustained peak abundance (ca. 30-60\%), including non-classic morphotypes with $\geq 4$ ocelli at the valve centre. Subzone D-3b (511-449 cm; ca. 9000-8200 cal yr BP) is characterised by an increased abundance of $S$. transylvanicus, and C. ocellata consists mainly of the classic morphotype (three ocelli).

In Zone D-4 (449-269 cm; ca. 8200-2600 cal yr BP), $C$. fottii is at high abundance (ca. 60-85\%), S. transylvanicus is consistently present at ca. 5-10\% abundance, and C. ocellata is at relatively low abundance (ca. 10-20\%), with a decline in diatom PCA Axis 1 scores and diatom concentration.

In Zone D-5 (269-214 cm; ca. 2600-2000 cal yr BP), $C$. ocellata shows renewed high abundance (ca. 50-60\%), with an increase in diatom PCA Axis 1 scores. Diatom concentration is relatively high.

In Zone D-6 $(214-0 \mathrm{~cm}$; ca. 2000 cal yr BP-present $), C$. ocellata is abundant (ca. 25-60\%), and there is increased but fluctuating abundance of $C$. minuscula, showing a sharp peak (ca. $35 \%$ abundance) at the lower zone boundary. Diatom PCA Axis 1 scores are high, but diatom concentration is low.

\section{Interpretation}

The limnological interpretation of diatoms rests in part on previous studies (Stanković, 1960; Allen and Ocevski, 1976; Ocevski and Allen, 1977), which found that endemic C. fottii occupies the hypolimnion throughout the year in Lake Ohrid. Cyclotella fottii is described as oligothermic and oligophotic, and it is thought to be an opportunistic species which extends its growth into the epilimnion during periods of low temperature in winter and early spring (Stanković, 1960). Stephanodiscus transylvanicus probably has similar ecological preferences to other intermediate- to large-sized Stephanodiscus species by virtue of their morphological similarity (Bradbury, 1991) and has been described as hypolimnetic (Stanković, 1960; Allen and Ocevski, 1976) and mesotrophic 


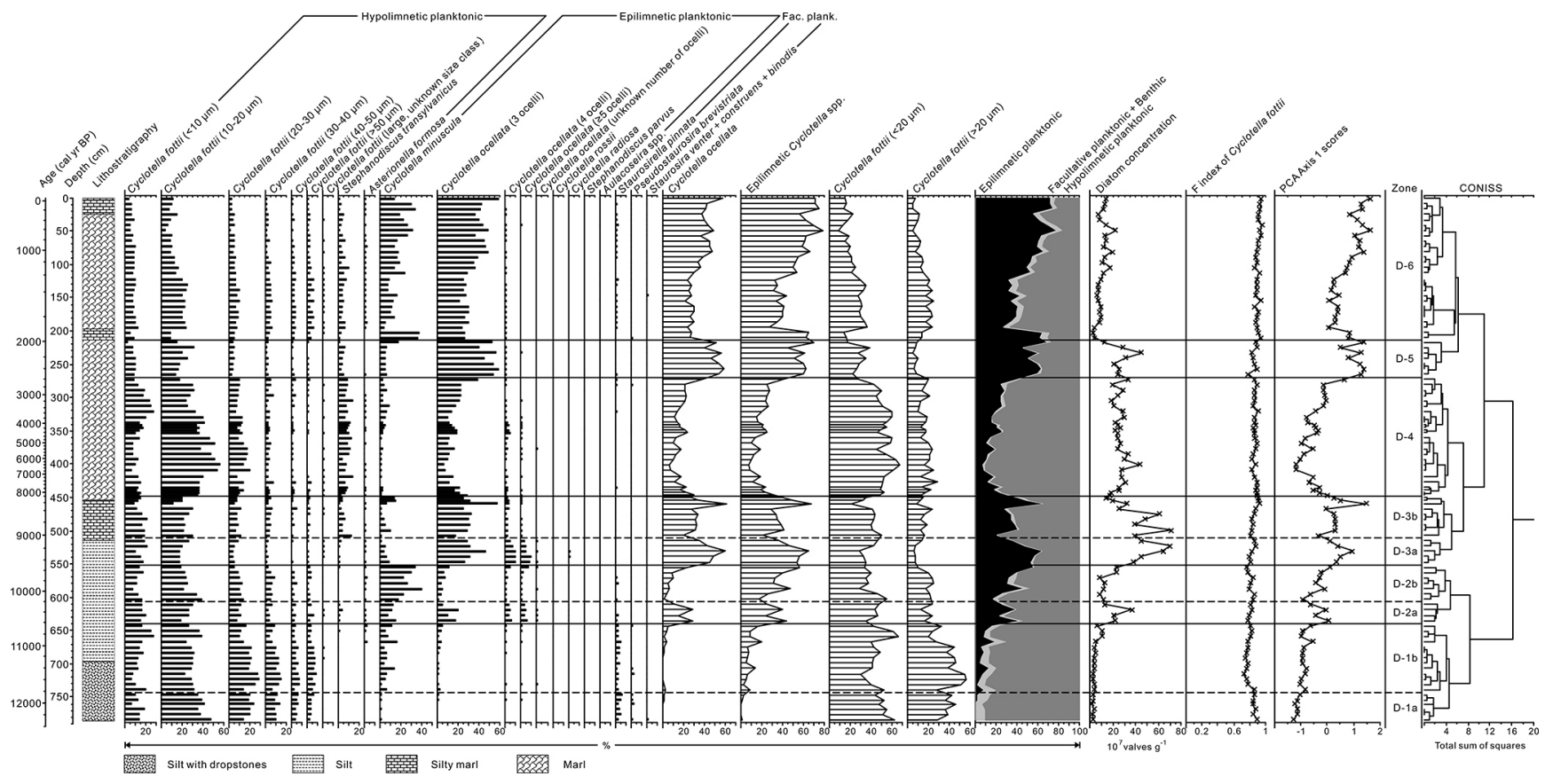

Figure 3. Summary diatom diagram of relative abundance of planktonic and facultative planktonic species from core Co1262, showing lithostratigraphy (modified from Wagner et al., 2012), diatom concentration, $C$. fottii $F$ index values, and principal component analysis (PCA) Axis 1 scores.

(Wagner et al., 2009). Cyclotella ocellata (and by inference C. minuscula) adopts an epilimnetic life habit in Lake Ohrid, thrives mainly in late spring and summer, and is described as eurythermic (Stanković, 1960). It has been described as mesotrophic (Wagner et al., 2009) and is taken as an indicator of nutrient enrichment in this highly oligotrophic lake compared to C. fottii (Lorenschat et al., 2014). Cyclotella ocellata is also found to be favoured by high nitrogen concentration in shallower, mesotrophic Lake Prespa, the sister lake of Lake Ohrid (Kocev et al., 2010). Cyclotella minuscula is very small (3-5 $\mu \mathrm{m}$ diameter), and probably has a similar ecological niche as other small-celled Cyclotella sensu lato species (Saros and Anderson, 2015), which have low nutrient and light requirements, high growth rates and low sinking rates, owing to their high ratio of surface area to volume (Winder et al., 2009; Finkel et al., 2009).

In contrast to the hypothesis of a linear response to temperature suggested in earlier, low-resolution diatom studies (Roelofs and Kilham, 1983; Wagner et al., 2009; Reed et al., 2010; Cvetkoska et al., 2012), we think that variations in the relative abundance of these taxa may be a direct response to shifts in temperature-induced lake productivity, but we should also consider the possible influence of temperature-related stratification or mixing regime, wind forcing, catchment mediation, light limitation, and/or spring inflow. It should be noted that temperature here is mean annual epilimnetic water temperature ("water temperature" hereafter). Lake Ohrid is still highly oligotrophic and ex- ceptionally transparent (Matzinger et al., 2006a, 2007), and hypolimnetic diatoms can be found at $>200 \mathrm{~m}$ water depth (Stanković, 1960), so light limitation can be assumed to be insignificant. Although Lorenschat et al. (2014) suggested that karstic springs from Lake Prespa have a strong influence on the nutrient budget of Lake Ohrid, it is apparent that spring inflow and associated nutrient transport do not reach the site of core Co1262 in the westernmost part of the lake (Matzinger et al., 2006a), and thus the direct influence of springs is probably negligible.

From the results of this study, the complacency in $C$. fottii $F$ index values and high quality of diatom preservation (Fig. 3) indicate that major shifts in diatom composition are not related to the taphonomic effects of dissolution but represent real ecological shifts. Diatom PCA Axis 1 scores clearly vary according to the relative abundance of the epilimnetic taxa, with high positive scores associated with the dominance of epilimnetic taxa and high negative scores in zones of lowdiversity $C$. fottii dominance. To strengthen interpretation, the diatom results of core Co1262 are compared with calcite $\left(\mathrm{CaCO}_{3}\right)$ and organic matter (i.e. total organic carbon, TOC) content and Rock Eval pyrolysis data (hydrogen index, HI; oxygen index, OI) from the same core (Fig. 4; Wagner et al., 2012; Lacey et al., 2015). Calcite content in particular has proved to be a strong proxy for temperature-induced productivity in this lake (Vogel et al., 2010; Wagner et al., 2010). Diatom shifts in core Co1262 are well correlated with those of core Lz1120 (Fig. 5; Wagner et al., 2009), validating diatom 


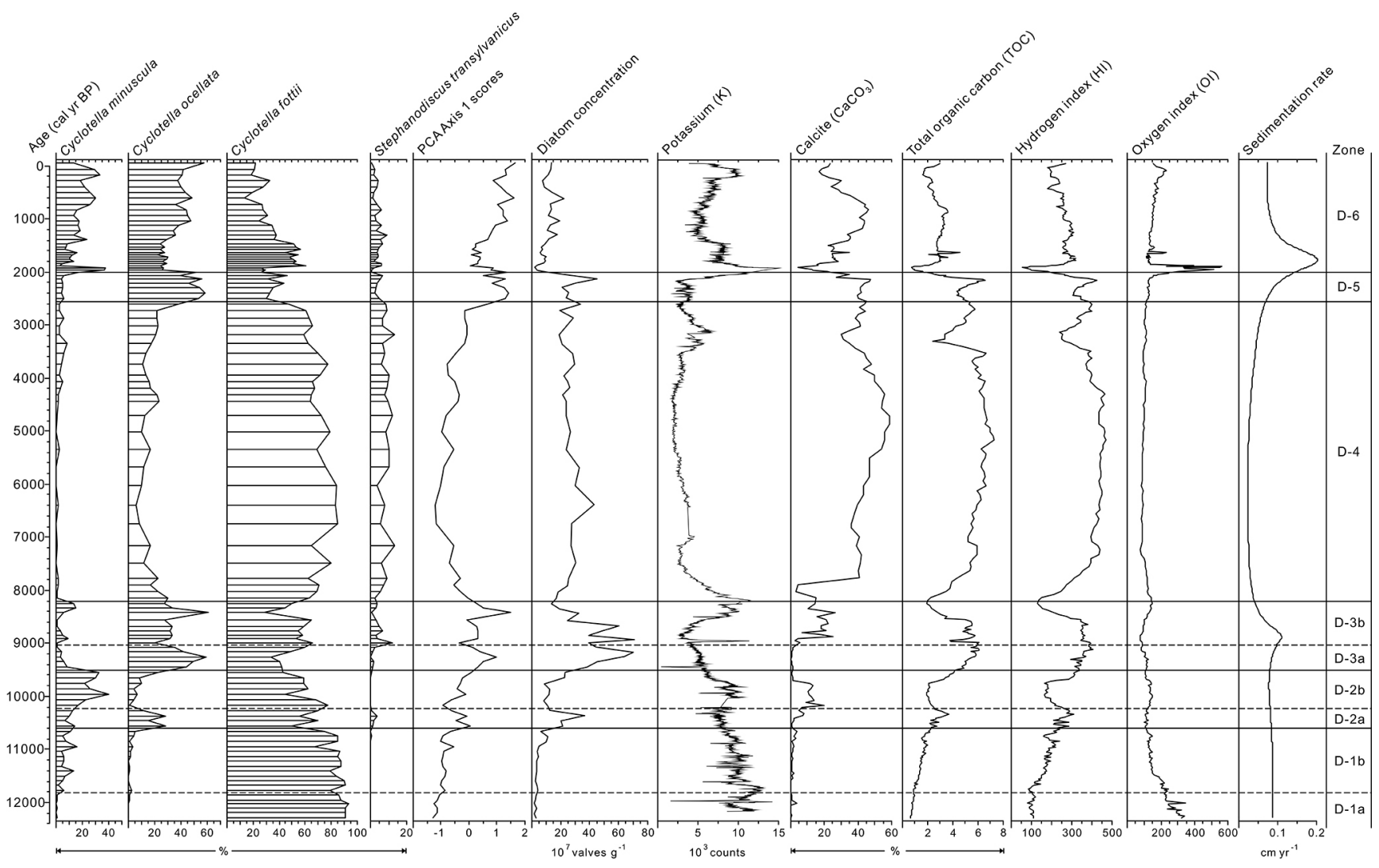

Figure 4. Comparison of diatoms in core $\mathrm{Co} 1262$ with sedimentological and geochemical data from the same core. $\mathrm{Calcite}(\mathrm{CaCO} 3)$ content and potassium (K) concentration are from Wagner et al. (2012), and total organic carbon (TOC) content, hydrogen index (HI) and oxygen index (OI) are from Lacey et al. (2015).

interpretation of core Co1262 as representative of basin-wide response. The possible influence of catchment dynamics and nutrient delivery is assessed through comparison with sedimentological potassium $(\mathrm{K})$ intensity and sedimentation rate data from the same core (Fig. 4; Wagner et al., 2012; Lacey et al, 2015), with palynological data from previous lake sediment cores in Lake Ohrid (Fig. 5; Wagner et al., 2009) and Lake Prespa (Panagiotopoulos et al., 2013), and with calcite $\delta^{18} \mathrm{O}$ data from existing sediment cores in Lake Ohrid (Leng et al., 2010; Lacey et al., 2015).

\subsection{The Lateglacial (ca. 12 300-11 800 cal yr BP)}

During the Lateglacial or Younger Dryas (Subzone D-1a; ca. 12 300-11 800 cal yr BP), the low-diversity dominance of hypolimnetic, oligothermic and oligophotic $C$. fottii indicates low lake productivity in relation to low water temperature, as during Marine Isotope Stage 2 (MIS 2) in core 9 (Roelofs and Kilham, 1983), core Co1202 (Reed et al., 2010), and the DEEP site (Cvetkoska et al., 2015). This corresponds to low calcite content, and this is also consistent with low organic matter content, low $\mathrm{HI}$ and high OI, which suggest low algal organic matter contribution and/or high organic matter degradation (Lacey et al., 2015). The regularly-distributed (ca. $8 \%$ relative abundance) pioneering, facultative planktonic fragilaroid taxa S. pinnata and $P$. brevistriata are probably related to cold water and winter lake ice cover (Mackay et al., 2003; Schmidt et al., 2004), which is consistent with the deposition of ice-rafted debris inferred from the occurrence of gravel grains ("silt with dropstones" in "lithostratigraphy" in Fig. 3; Wagner et al., 2012). These taxa are also probably related to physical disturbance (Anderson, 2000), which is consistent with intense lake circulation as a result of low water temperature and strong winds (see below). Low water temperature would have resulted in the high frequency and long duration of complete lake circulation which usually occurs in severe winters or following intense wind action in less severe winters in this lake today (Stanković, 1960). If subject to winter lake ice cover, this lake would have been dimictic or monomictic rather than currently oligomictic. Low water temperature during the Younger Dryas in this lake is consistent with pollen-based air temperature reconstruction in Lake Maliq (Albania; Bordon et al., 2009), and SL152 (northern Aegean Sea; Kotthoff et al., 2011), with alkenoneand foram-inferred low sea surface temperature (SST) in MNB3 (northern Aegean Sea; Gogou et al., 2007; Geraga et al., 2010), and with the globally stacked proxy surface 
temperature record (Shakun et al., 2012). Intense wind action may have occurred during this cold period (Vogel et al., 2010), in accordance with the observation that average wind speed in winter is higher than in summer today (Stanković, 1960). Thus, the capacity for mixing-induced upward nutrient supply would have been high. High sedimentation rate, high $\mathrm{K}$ intensity (i.e. high clastic content), and low calcite and organic matter content (i.e. low authigenic matter content) suggest high catchment erosion. This is supported by sparse vegetation and unsettled soils in the catchment during the Younger Dryas (Panagiotopoulos et al., 2013). Thus, erosion-induced external nutrient input would also have been high. However, Younger Dryas water temperature must have been low enough to prevent nutrient-induced productivity increase.

\subsection{The earliest Holocene (ca. 11 800-10 600 cal yr BP)}

After the Lateglacial, the slight increase in the relative abundance of small, epilimnetic $C$. minuscula during the earliest Holocene (Subzone D-1b; ca. 11 800-10 600 cal yr BP) is surprisingly subtle. It is consistent with the inherent response of small planktonic diatoms to climate warming and enhanced thermal stratification with reduced epilimnetic nutrient availability and/or increased sinking velocities in a deep, oligotrophic lake (Winder et al., 2009; Finkel et al., 2009; Jewson et al., 2015). Less intense winds and prolonged calm periods may be another factor contributing to the increase in $C$. minuscula in this deep, oligomictic lake. The rarity ( $<5 \%$ relative abundance) of facultative planktonic taxa suggests either a shorter, less intense period of lake circulation, in accordance with the increase in C. minuscula, or a more prolonged ice-free period, in accordance with the disappearance of ice-rafted debris deposition after ca. 11300 cal yr BP (Wagner et al., 2012). The increase in the abundance of epilimnetic Cyclotella species is also possibly related to a longer ice-free season (Smol et al., 2005; Rühland et al., 2008). There is a gradual rather than abrupt change in increasing organic matter content, increasing $\mathrm{HI}$ and decreasing OI, which indicate relatively subtle increases in algal organic matter contribution and/or organic matter preservation (Lacey et al., 2015). However, diatom concentration remains as low as during the Lateglacial. Sedimentation rate remains constant (Fig. 4), and in terms of the possible influence of diatom cell size, an increase in the abundance of large $C$. fottii morphotypes (> $20 \mu \mathrm{m}$ ) may compensate for the increase in small C. minuscula (Fig. 3). In combination with low calcite content, low diatom concentration thus indicates that water temperature is still very low during this period, possibly with only intermittent stratification. Although the diatom signature of the Lateglacial-Holocene transition is more pronounced here than in core Co1202 (Reed et al., 2010), the transition is remarkably muted compared to the marked diatom shifts observed in shallower southern Balkan lakes. The distinct transition in Lake Ioannina (northwest- ern Greece; Wilson et al., 2008; Jones et al., 2013), Lake Prespa (Macedonia, Albania and Greece; Cvetkoska et al., 2014b), and Lake Dojran (Macedonia and Greece; Zhang et al., 2014), for example, is instead a response driven by a major increase in lake level and moisture availability. The temperature shift was insufficient to cause a major productivity increase in this deep lake, although high sedimentation rate, high $\mathrm{K}$ intensity and low authigenic matter content probably indicate high catchment erosion and associated nutrient delivery similar to the Lateglacial environment. The results also confirm the potential of Lake Ohrid's contrasting response thresholds to contribute to the separation of temperature and precipitation change in regional palaeoclimate reconstruction. However, muted water temperature increase in this lake is not consistent with a distinctly increasing trend for the globally stacked proxy mean annual surface temperature (Shakun et al., 2012; Marcott et al., 2013).

\subsection{The early Holocene (ca. $10600-8200$ cal yr BP)}

The early Holocene (Zones D-2 and D-3; ca. 106008200 cal yr BP) is marked by a sustained increase in the abundance of epilimnetic taxa, with an alternation between C. ocellata and C. minuscula in Zone D-2 (ca. 106009500 cal yr BP) and dominance by $C$. ocellata in Zone D-3 (ca. 9500-8200 cal yr BP). Diatom PCA Axis 1 scores are correspondingly high. Since sedimentation rate is nearly unchanged compared to Zone D-1 (Fig. 4), high diatom concentration in Subzone D-2a and Zone D-3 might be attributed to reduced abundance of large $C$. fottii morphotypes and increased abundance of relatively small $C$. ocellata, but high abundance of very small C. minuscula in Subzone D-2b is associated with low rather than high diatom concentration (Fig. 3). Thus, diatom concentration could still indicate a real change in lake productivity during the early Holocene. High abundance of eurythermic, mesotrophic $C$. ocellata between ca. 10 600-10 200 cal yr BP (Subzone D-2a) and between ca. 9500-8200 cal yr BP (Zone D-3) corresponds to high diatom concentration and high organic matter content, supporting an interpretation of $C$. ocellata as indicative of high watertemperature-induced lake productivity, as in core Co1202 (Reed et al., 2010). This is also consistent with generally high $\mathrm{HI}$ and slightly low OI, reflecting high algal organic matter contribution and/or better organic matter preservation (Lacey et al., 2015). High water temperature clearly implies high air temperature, although the converse does not necessarily apply since low water temperature occurred during the earliest Holocene. High temperature and possibly associated low winter wind stress would have reduced the frequency, duration and strength of lake circulation and thus restrained nutrient availability in the epilimnion. Nearly constant sedimentation rate (compared to Zone D-1), generally low $\mathrm{K}$ intensity and high organic matter content in the diatom zones D-2a and D-3 probably represent a decline in catchment erosion and associated nutrient delivery rather than dilution ef- 


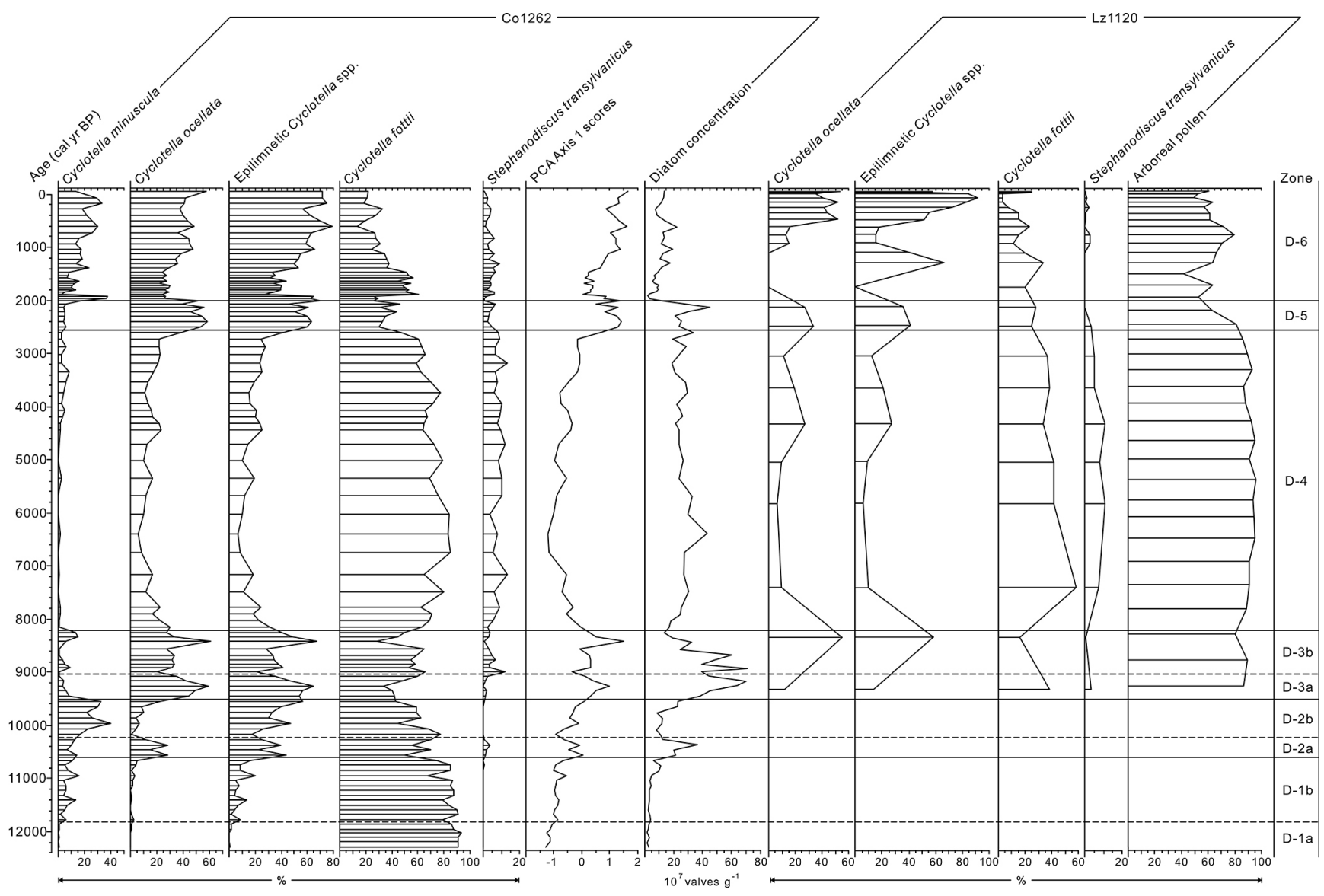

Figure 5. Comparison of diatoms in core Co1262 with diatom and palynological data from core Lz1120, southeastern Lake Ohrid (Wagner et al., 2009).

fects. This is consistent with dense forest and stable soils in the catchment (Wagner et al., 2009; Panagiotopoulos et al., 2013). However, nutrient concentration must have been insufficiently low to prevent a temperature-induced productivity increase.

High C. minuscula abundance between ca. 10200 9500 cal yr BP (Subzone D-2b), at the expense of C. ocellata, corresponds to a major peak in calcite content. Given primarily photosynthesis-induced calcite precipitation in this lake, with negligible detrital calcite and minor contribution of calcite precipitated around spring areas, the peak calcite content indicates high lake productivity and, by inference, high water temperature (Vogel et al., 2010; Wagner et al., 2010). However, a contrasting diatom ecological response is shown in this subzone, with high C. minuscula abundance and low diatom concentration. Although, as suggested above, strong stratification would support the bloom of small-sized planktonic diatom species, low diatom concentration is not consistent with the inferred high water-temperature-induced productivity. Sedimentation rate is nearly unchanged compared to Subzone D-2a, and, under a densely-vegetated catchment (Panagiotopoulos et al., 2013), high K intensity in Subzone
D-2b, along with low organic matter content and relatively high calcite content, does not necessarily imply high catchment erosion, possibly due to dilution effects. In contrast to Subzone D-2a and Zone D-3, it is most likely in Subzone $\mathrm{D}-2 \mathrm{~b}$ that, corresponding to the peak calcite content, more nutrients such as phosphorus are lost from the epilimnion through being absorbed onto the surface of precipitating calcite particles (Allen and Ocevski, 1976). Epilimnetic nutrient availability in Subzone D-2b must have been low enough to prevent a high water-temperature-induced productivity increase. The significance of this shift was not highlighted in a previous study (Reed et al., 2010), wherein C. minuscula was separated only as a morphotype of $C$. ocellata.

An increase in the abundance of hypolimnetic, mesotrophic $S$. transylvanicus in Subzone D-3b (ca. 9000-8200 cal yr BP) corresponds to renewed calcite accumulation, and the lower boundary of this subzone is also coincident with an extreme, abrupt peak in $\mathrm{K}$ intensity, which originates from volcanic glass shards and corresponds to the Mercato tephra (Wagner et al., 2012). The tephra input would increase epilimnetic silica availability and reduce phosphorus release from the sediment (Barker et al., 2000; 
Telford et al., 2004), resulting in either an increase in diatom concentration (Lotter et al., 1995; Eastwood et al., 2002) or a shift of diatom composition to the dominance of taxa that require a high $\mathrm{Si} / \mathrm{P}$ ratio (Abella, 1988; Cruces et al., 2006). The tephra impact would also be short-lived, with a recovery of diatom composition towards the pre-tephra state (Telford et al., 2004; Cruces et al., 2006). It is apparent that the Mercato tephra has no impact on diatoms here, since $S$. transylvanicus maintains its abundance over the long term and diatom concentration maintains its maximum level. Moreover, most Stephanodiscus species prefer a low Si / P ratio (Kilham et al., 1986), which also suggests that the tephra has no impact. It is possible that $S$. transylvanicus is favoured by phosphorus release in the hypolimnion due to the dissolution of precipitating calcite and the mineralisation of settling organic matter from the upper layer (Stanković, 1960; Allen and Ocevski, 1976; Matzinger et al., 2006a, 2007). In all, during the early Holocene, high water temperature in this lake is in accordance with the globally stacked proxy mean annual surface temperature record (Marcott et al., 2013), and diatom species appear to respond to high water temperature in different ways: the response of $C$. ocellata is direct in relation to high water-temperature-induced epilimnetic productivity, while the response of $C$. minuscula is indirect in relation to nutrient limitation in the epilimnion. Lacey et al. (2015) interpreted the phase between ca. $8600-8000$ cal yr BP (ca. 600 years) as a response to the abrupt $8.2 \mathrm{ka}$ cooling event based on sedimentological and geochemical data. However, based on ca. 100-year resolution diatom data, there is no apparent diatom reversal to an oligothermic-type flora, and the decline in diatom concentration is more a long-term change associated with reduced sedimentation rate.

\subsection{The middle Holocene (ca. 8200-2600 cal yr BP)}

The middle Holocene (Zone D-4; ca. 8200-2600 cal yr BP) was a phase of maximum Holocene water temperature and lake productivity, as indicated strongly by high calcite and organic matter content, high HI and low OI (Vogel et al., 2010; Wagner et al., 2010; Lacey et al., 2015). This is in accordance with the globally stacked proxy mean annual surface temperature record (Marcott et al., 2013). However, the diatom response is complex. Anomalously, C. ocellata is at low abundance, with reduced diatom PCA Axis 1 scores. As in Subzone D-2b, this may be attributed to epilimnetic nutrient limitation, but to the extent that $C$. minuscula is also constrained. Mixing-induced upward nutrient supply is probably low, as a result of strong thermal stratification and probably weak winds associated with high temperature. Erosioninduced external nutrient input is also probably low, as indicated by a low sedimentation rate and $\mathrm{K}$ intensity (i.e. clastic content). Low catchment erosion is also supported by dense vegetation and stable soils in the catchment (Fig. 5; Wagner et al., 2009) and by a drying trend and reducing water inflow from rising calcite $\delta^{18} \mathrm{O}$ values (Leng et al., 2010; Lacey et al., 2015). The effect of high phosphorus precipitation linked to the calcite-scavenging effect (Allen and Ocevski, 1976), and exacerbated by a low internal and external nutrient supply, could be sufficient to limit the development of $C$. ocellata during the middle Holocene in spite of high water temperature. The only predictable aspect of the diatom data is the relatively high abundance of mesotrophic S. transylvanicus, which may benefit from high water-temperature-induced productivity in the hypolimnion and/or high nutrient availability in the hypolimnion under strong stratification. The flora is similar to that of the middle Holocene in core Lz1120 (Fig. 5; Wagner et al., 2009) and in the DEEP site (Cvetkoska et al., 2015). Compared to Zone D-1, although C. fottii is similarly at high abundance, the abundance of large $C$. fottii forms is much lower (Fig. 3) and fewer cells can complete their full life cycle with sexual reproduction (Stoermer et al., 1989), possibly linked to strong stratification during this period. Since high calcite and organic matter content indicates high algal production, the discrepancy between low abundance of epilimnetic diatom taxa and high algal production suggests that Chlorophyceae, the other dominant algae in this lake (Stanković, 1960; Miho and Lange-Bertalot, 2003), may outcompete diatoms in the epilimnion and contribute more to algal production. Diatom concentration is relatively high, in an interval with low rather than high abundance of smaller valves of $C$. ocellata and $C$. minuscula, but this may be largely an artefact of the consistently low sedimentation rate. As in other Lake Ohrid sediment cores (Wagner et al., 2009; Vogel et al., 2010), there is no evidence for an abrupt event at ca. $4200 \mathrm{cal}$ yr BP. Overall, in contrast to Zone D-1, low abundance of epilimnetic diatom taxa here is the response to high rather than low water temperature; in contrast to Zones D-2 and D-3, the diatom response here is to limited epilimnetic nutrient availability rather than high water-temperature-induced productivity.

\subsection{The late Holocene (ca. 2600 cal yr BP-present)}

Between ca. 2600-2000 cal yr BP (Zone D-5), high C. ocellata abundance, along with high diatom PCA Axis 1 scores, is consistent with that of core Lz1120 (Fig. 5; Wagner et al., 2009). There is surprisingly little change in other limnological proxies during this phase, but high $C$. ocellata abundance correlates with palynological evidence for anthropogenic catchment deforestation in core Lz1120 (Fig. 5; Wagner et al., 2009). Relatively high diatom concentration probably represents a response to epilimnetic productivity increase, caused at least in part by human activity such as forest clearance and agricultural development. At ca. 2000 or 1900 cal yr BP, the abrupt peak in C. minuscula abundance is coeval with peak sedimentation rate and $\mathrm{K}$ intensity, abrupt reductions in calcite, organic matter and $\mathrm{HI}$, and a peak in OI. The peak is consistent with previous interpretations, suggesting that it is related to intensified human activity in the 
catchment during the Roman Period and that enhanced erosion causes increased delivery of nutrients, clastic material and organic matter that is extensively oxidised (Wagner et al., 2009; Vogel et al., 2010; Lacey et al., 2015). It is a complex diatom response to high nutrient availability, however. While very small Cyclotella sensu lato species have low nutrient preferences, they may respond to nitrogen enrichment when the N / P supply ratio is low (Saros and Anderson, 2015). There is no abiotic mechanism for the removal of nitrogen from the epilimnion, and phosphorus precipitation linked to the calcite-scavenging effect is low at this time (Allen and Ocevski, 1976).

After ca. 1900 cal yr BP (Zone D-6), Lake Ohrid essentially reached its modern state with a high abundance of epilimnetic taxa, dominated by smaller valves of $C$. ocellata and C. minuscula, which is consistent with the flora of the late Holocene in the DEEP site (Cvetkoska et al., 2015). As suggested in the previous zones, the autecology of $C$. ocellata and $C$. minuscula is probably divergent in relation to nutrient availability and mixing depth, which is supported by other observational and experimental studies (e.g. Saros et al., 2012); on the other hand, C. ocellata is relatively small and may also show synchronous change with very small $C y$ clotella sensu lato species (e.g. Rühland et al., 2008). Moreover, high nitrogen concentration may favour both $C$. ocellata and C. minuscula (Kocev et al., 2010; Saros and Anderson, 2015). Thus, it is not surprising that $C$. ocellata and $C$. minuscula concur to respond to enhanced anthropogenic nutrient input during this period. There is strong palynological evidence for catchment deforestation after ca. 1900 cal yr BP from core Lz1120 and Lake Prespa core Co1215 (Wagner et al., 2009; Panagiotopoulos et al., 2013). There is no definitive evidence for a diatom response to known late-Holocene climatic events such as the Medieval Climate Anomaly (MCA) or the Little Ice Age (LIA). If a strong MCA did occur, anthropogenic nutrient input to the modern lake was sufficient to override temperature-induced nutrient limitation in the epilimnion. With external nutrient input maintained at the same level, the implications for future climate warming are that loss of epilimnetic diversity would not occur. Instead, the main threat to Lake Ohrid is probably eutrophication, resulting in the invasion of non-native taxa (Levkov and Williams, 2012).

\section{Conclusions}

This study provides a detailed picture of the diatom response to Lateglacial and Holocene climate and environmental change in Lake Ohrid, based on diatom analysis of core Co1262 and comparison with sedimentological and geochemical data from the same core, with extant low-resolution diatom data and with palynological evidence for catchment vegetation change. Since most Mediterranean lakes are relatively shallow, with a strong diatom response to lake-level change linked to moisture availability rather than temperature, this study is important in improving our understanding of the strength and complexity of diatom response to water temperature change in deep, oligotrophic Lake Ohrid. Our multi-proxy analysis reveals that water temperature was low during the Lateglacial and even the earliest Holocene, was high during the early Holocene, and reached the maximum during the middle Holocene, but that the diatom response is strongly non-linear, and coherent interpretation requires consideration of the influence of multiple limnological parameters which vary in their importance over time. The data are at least consistent with a direct response of diatoms to temperature-induced lake productivity in some phases, but in others an indirect response to temperature-related lake stratification or mixing and epilimnetic nutrient availability may occur. We demonstrate the possible additional influence of physical limnological (e.g. the influence of wind stress on stratification or mixing) and chemical processes (e.g. the influence of catchment dynamics on nutrient input).

During the Lateglacial (ca. 12300-11 $800 \mathrm{cal} \mathrm{yr} \mathrm{BP),} \mathrm{the}$ low-diversity dominance of hypolimnetic $C$. fottii indicates low lake productivity in relation to low water temperature. During the earliest Holocene (ca. 11 800-10 600 cal yr BP), although the slight increase in small, epilimnetic C. minuscula probably represents climate warming and enhanced stratification, diatom concentration is as low as during the Lateglacial, indicating that water temperature increase was muted. The early Holocene (ca. $10600-8200$ cal yr BP) is characterised by a sustained increase in epilimnetic taxa, with mesotrophic $C$. ocellata indicating high watertemperature-induced lake productivity between ca. 10600 $10200 \mathrm{cal} \mathrm{yr} \mathrm{BP}$ and between ca. 9500-8200 cal yr BP and with $C$. minuscula in response to low nutrient availability in the epilimnion between ca. 10200-9500 cal yr BP. During the middle Holocene (ca. 8200-2600 cal yr BP), in spite of maximum Holocene water temperature, anomalously low C. ocellata abundance is probably a response to epilimnetic nutrient limitation, as a result of high temperaturerelated stratification (i.e. low internal nutrient upward supply), low catchment erosion (i.e. low external nutrient input) and the calcite-scavenging effect (i.e. high phosphorus precipitation). However, mesotrophic S. transylvanicus may benefit from high water-temperature-induced productivity in the hypolimnion and/or high nutrient availability in the hypolimnion under strong stratification. During the late Holocene (ca. 2600 cal yr BP-present), high abundance and the fluctuating composition of epilimnetic taxa are largely a response to enhanced anthropogenic nutrient input, particularly nitrogen enrichment.

Author contributions. B. Wagner, M. J. Leng and J. M. Reed designed this research in the SCOPSCO project. X. S. Zhang performed diatom analysis. X. S. Zhang and J. M. Reed interpretated diatom data by comparison with other proxy data. A. Francke and B. Wagner developed the age model. A. Francke and B. Wag- 
ner generated and interpretated sedimentological and geochemical data (sedimentation rate, potassium concentration and calcite content). J. H. Lacey and M. J. Leng generated and interpretated geochemical data (total organic carbon content, hydrogen index and oxygen index). Z. Levkov provided information on developments in diatom taxonomy. X. S. Zhang wrote the paper under the supervision of J. M. Reed with editorial comments from all coauthors.

Acknowledgements. The study was funded by a University of Hull-China Scholarship Council (CSC) PhD Scholarship to X. S. Zhang. It is part of the project Scientific Collaboration on Past Speciation Conditions in Lake Ohrid (SCOPSCO), supported by the International Continental Scientific Drilling Program (ICDP), the German Federal Ministry of Education and Research (BMBF), the German Research Foundation (DFG), the University of Cologne, the British Geological Survey (BGS), the Italian National Institute of Geophysics and Volcanology (INGV), the Italian National Research Council (CNR), and the Governments of the Republics of Macedonia (FYROM) and Albania. Many thanks are due to Jens Holtvoeth, Klaus Reicherter and Daniel Ariztegui for discussions of human impacts and adaption in the 4th SCOPSCO workshop in Hull, UK. Thanks are also due to Aleksandra Cvetkoska, Elena Jovanovska and Aleksandar Pavlov for discussions of diatom taxonomy. We also would like to thank Thomas Wilke, Anson Mackay, Patrick Rioual and Keely Mills very much for their detailed and constructive comments, suggestions and improvements regarding the manuscript.

Edited by: T. Wilke

\section{References}

Abella, S. E. B.: The effect of the Mt. Mazama ashfall on the planktonic diatom community of Lake Washington, Limnol. Oceanogr., 33, 1376-1385, 1988.

Albrecht, C. and Wilke, T.: Ancient Lake Ohrid: biodiversity and evolution, Hydrobiologia, 615, 103-140, 2008.

Allen, H. L. and Ocevski, B. T.: Limnological studies in a large, deep, oligotrophic lake (Lake Ohrid, Yugoslavia): evaluation of nutrient availability and control of phytoplankton production through in situ radiobioassay procedures, Arch. Hydrobiol., 77, 1-21, 1976.

Anderson, N. J.: Diatoms, temperature and climatic change, Eur. J. Phycol., 35, 307-314, 2000.

Barker, P., Telford, R., Merdaci, O., Williamson, D., Taieb, M., Vincens, A., and Gibert, E.: The sensitivity of a Tanzanian crater lake to catastrophic tephra input and four millennia of climate change, Holocene, 10, 303-310, 2000.

Battarbee, R. W., Jones, V. J., Flower, R. J., Cameron, N. G., and Bennion, H.: Diatoms, in: Tracking Environmental Change Using Lake Sediments Vol. 3: Terrestrial, Algal, and Siliceous Indicators, edited by: Smol, J. P., Birks, H. J. B., and Last, W. M., Kluwer Academic Publishers, Dordrecht, The Netherlands, 155202, 2001.
Birks, H. J. B., Heiri, O., Seppä, H., and Bjune, A. E.: Strengths and weaknesses of quantitative climate reconstructions based on lateQuaternary biological proxies, Open Ecol. J., 3, 68-110, 2010.

Blaauw, M.: Methods and code for "classical" age-modelling of radiocarbon sequences, Quat. Geochronol., 5, 512-518, 2010.

Bordon, A., Peyron, O., Lézine, A. M., Brewer, S., and Fouache, E.: Impact of Lateglacial cold events on the northern Aegean region reconstructed from marine and terrestrial proxy data, Quaternary Int., 200, 19-30, 2009.

Bradbury, J. P.: The late Cenozoic diatom stratigraphy and paleolimnology of the Tule Lake, Siskiyou Co. California, J. Paleolimnol., 6, 205-255, 1991.

Cruces, F., Urrutia, R., Parra, O., Araneda, A., Treutler, H., Bertrand, S., Fagel, N., Torres, L., Barra, R., and Chirinos, L., Changes in diatom assemblages in an Andean lake in response to a recent volcanic event, Arch. Hydrobiol., 165, 23-35, 2006.

Cvetkoska, A., Reed, J. M., and Levkov, Z.: Diatoms as Indicators of Environmental Change in Ancient Lake Ohrid during the Last Glacial-Interglacial Cycle (ca. $140 \mathrm{ka}$ ), in: Diatom Monographs Vol. 15, edited by: Witkowski, A., A.R.G. Gantner Verlag, Ruggell, Liechtenstein, 2012.

Cvetkoska, A., Hamilton, P. B., Ognjanva-Rumenova, N., and Levkov, Z.: Observations of the genus Cyclotella (Kützing) Brébisson in ancient lakes Ohrid and Prespa and a description of two new species $C$. paraocellata sp. nov. and $C$. prespanensis spec. nov., Nova Hedwigia, 98, 313-340, 2014a.

Cvetkoska, A., Levkov, Z., Reed, J. M., and Wagner, B.: Late glacial to Holocene climate change and human impact in the Mediterranean: the last ca. $17 \mathrm{ka}$ diatom record of Lake Prespa (Macedonia/Albania/Greece), Paleogeogr. Paleoecol., 406, 22-32, 2014b.

Cvetkoska, A., Jovanovska, E., Francke, A., Tofilovska, S., Vogel, H., Levkov, Z., Donders, T. H., Wagner, B., and Wagner-Cremer, F.: Ecosystem regimes and responses in a coupled ancient lake system from MIS 5b to present: the diatom record of lakes Ohrid and Prespa, Biogeosciences Discuss., under review, 12, 1505115086, doi:10.5194/bgd-12-15051-2015, 2015.

Damaschke, M., Sulpizio, R., Zanchetta, G., Wagner, B., Böhm, A., Nowaczyk, N., Rethemeyer, J., and Hilgers, A.: Tephrostratigraphic studies on a sediment core from Lake Prespa in the Balkans, Clim. Past, 9, 267-287, doi:10.5194/cp-9-267-2013, 2013.

Dormoy, I., Peyron, O., Combourieu Nebout, N., Goring, S., Kotthoff, U., Magny, M., and Pross, J.: Terrestrial climate variability and seasonality changes in the Mediterranean region between 15000 and 4000 years BP deduced from marine pollen records, Clim. Past, 5, 615-632, doi:10.5194/cp-5-615-2009, 2009.

Eastwood, W. J., Tibby, J., Roberts, N., Birks, H. J. B., and Lamb, H. F.: The environmental impact of the Minoan eruption of Santorini (Thera): statistical analysis of palaeoecological data from Gölhisar, southwest Turkey, Holocene, 12, 431-444, 2002.

Finkel, Z. V., Vaillancourt, C. J., Irwin, A. J., Reavie, E. D., and Smol, J. P.: Environmental control of diatom community size structure varies across aquatic ecosystems, Proc. R. Soc. B-Biol. Sci., 276, 1627-1634, 2009.

Fourtanier, E. and Kociolek, J. P.: Catalogue of Diatom Names, online version (updated 19 Sep 2011), California Academy of Sciences, San Francisco, USA, 2011.

Francke, A., Wagner, B., Just, J., Leicher, N., Gromig, R., Baumgarten, H., Vogel, H., Lacey, J. H., Sadori, L., Wonik, T., Leng, 
M. J., Zanchetta, G., Sulpizio, R., and Giaccio, B.: Sedimentological processes and environmental variability at Lake Ohrid (Macedonia, Albania) between $637 \mathrm{ka}$ and the present, Biogeosciences, 13, 1179-1196, doi:10.5194/bg-13-1179-2016, 2016.

Geraga, M., Ioakim, C., Lykousis, V., Tsaila-Monopolis, S., and Mylona, G.: The high-resolution palaeoclimatic and palaeoceanographic history of the last 24000 years in the central Aegean Sea, Greece, Paleogeogr. Paleoecol., 287, 101-115, 2010.

Gogou, A., Bouloubassi, I., Lykousis, V., Arnaboldi, M., Gaitani, P., and Meyers, P. A.: Organic geochemical evidence of Late Glacial-Holocene climate instability in the North Aegean Sea, Paleogeogr. Paleoecol., 256, 1-20, 2007.

Grimm, E. C.: Tilia Version 1.7.16, Illinois State Museum, Springfield, USA, 2011.

Hoffmann, N., Reicherter, K., Fernández-Steeger, T., and Grützner, C.: Evolution of ancient Lake Ohrid: a tectonic perspective, Biogeosciences, 7, 3377-3386, doi:10.5194/bg-7-3377-2010, 2010.

Houk, V., Klee, R., and Tanaka, H.: Atlas of Freshwater Centric Diatoms with a Brief Key and Description, Part III Stephanodiscaceae A: Cyclotella, Tertiarius, Discostella, Czech Phycological Society, Prague, Czech Republic, 2010.

Houk, V., Klee, R., and Tanaka, H.: Atlas of Freshwater Centric Diatoms with a Brief Key and Description, Part IV Stephanodiscaceae B: Stephanodiscus, Cyclostephanos, Pliocaenicus, Hemistephanos, Stephanocostis, Mesodictyon \& Spicaticribra, Czech Phycological Society, Prague, Czech Republic, 2014.

Hustedt, F.: Diatomeen aus Seen und Quellgebieten der BalkanHalbinsel (Diatoms from lakes and springs of the Balkan Peninsula), Arch. Hydrobiol., 40, 867-973, 1945.

Jewson, D. H., Granin, N. G., Gnatovsky, R. Yu., Lowry, S. F., and Teubner, K.: Coexistence of two Cyclotella diatom species in the plankton of Lake Baikal, Freshwater Biol., 60, 2113-2126, 2015.

Jones, T. D., Lawson, I. T., Reed, J. M., Wilson, G. P., Leng, M. J., Gierga, M., Bernasconi, S. M., Smittenberg, R. H., Hajdas, I., Bryant, C. L., and Tzedakis, P. C.: Diatom-inferred late Pleistocene and Holocene palaeolimnological changes in the Ioannina basin, northwest Greece, J. Paleolimnol., 49, 185-204, 2013.

Juggins, S. and Birks, H. J. B.: Quantitative environmental reconstructions from biological data, in: Tracking Environmental Change Using Lake Sediments Vol. 5: Data Handling and Numerical Techniques, edited by: Birks, H. J. B., Lotter, A. F., Juggins, S., and Smol, J. P., Springer, Dordrecht, the Netherlands, 431-494, 2012.

Jurilj, A.: Flora i vegetacija dijatomeja Ohridskog jezera (Flora and vegetation of diatoms from Ohrid Lake in Yugoslavia), Jugoslavenska Akademija Znanosti i Umjetnosti (Yugoslavian Academy of Science), 26, 99-190, 1954.

Kilham, P., Kilham, S. S., and Hecky, R. E.: Hypothesized resource relationships among African planktonic diatoms, Limnol. Oceanogr., 31, 1169-1181, 1986.

Kocev, D., Naumoski, A., Mitreski, K., Krstić, S., and Džeroski, S.: Learning habitat models for the diatom community in Lake Prespa, Ecol. Model., 221, 330-337, 2010.

Kotthoff, U., Koutsodendris, A., Pross, J., Schmiedl, G., Bornemann, A., Kaul, C., Marino, G., Peyron, O., and Schiebel, R.: Impact of Lateglacial cold events on the northern Aegean region reconstructed from marine and terrestrial proxy data, J. Quaternary Sci., 26, 86-96, 2011.
Krammer, K.: Cymbella, in: Diatoms of Europe, Diatoms of the European Inland Waters and Comparable Habitats Vol. 3, edited by: Lange-Bertalot, H., A.R.G. Gantner Verlag, Ruggell, Liechtenstein, 2002.

Krammer, K. and Lange-Bertalot, H.: Bacillariophyceae, Teil 1: Naviculaceae, in: Süsswasserflora von Mitteleuropa, Bd. 2/1, edited by: Ettl, H., Gerloff, J., Heynig, H., and Mollenhauer, D., Gustav Fischer Verlag, Stuttgart, Germany, 1986.

Krammer, K. and Lange-Bertalot, H.: Bacillariophyceae, Teil 2: Epithemiaceae, Bacillariaceae, Surirellaceae, in: Süsswasserflora von Mitteleuropa, Bd. 2/2, edited by: Ettl, H., Gerloff, J., Heynig, H., and Mollenhauer, D., Gustav Fischer Verlag, Stuttgart, Germany, 1988.

Krammer, K. and Lange-Bertalot, H.: Bacillariophyceae, Teil 3: Centrales, Fragilariaceae, Eunotiaceae, in: Süsswasserflora von Mitteleuropa, Bd. 2/3, edited by: Ettl, H., Gerloff, J., Heynig, H., and Mollenhauer, D., Gustav Fischer Verlag, Stuttgart, Germany, 1991a.

Krammer, K. and Lange-Bertalot, H.: Bacillariophyceae, Teil 4: Achnanthaceae, Kritische Ergänzungen zu Navicula (Lineolatae) und Gomphonema, in: Süsswasserflora von Mitteleuropa, Bd. 2/4, edited by: Ettl, H., Gerloff, J., Heynig, H., and Mollenhauer, D., Gustav Fischer Verlag, Stuttgart, Germany, 1991b.

Lacey, J. H., Francke, A., Leng, M. J., Vane, C. H., and Wagner, B.: A high-resolution Late Glacial to Holocene record of environmental change in the Mediterranean from Lake Ohrid (Macedonia/Albania), Int. J. Earth Sci., 104, 1623-1638, 2015.

Lange-Bertalot, H.: Navicula sensu stricto, 10 genera separated from Navicula sensu lato, Frustulia, in: Diatoms of Europe, Diatoms of the European Inland Waters and Comparable Habitats Vol. 2, edited by: Lange-Bertalot, H., A.R.G. Gantner Verlag, Ruggell, Liechtenstein, 2001.

Leng, M. J., Baneschi, I., Zanchetta, G., Jex, C. N., Wagner, B., and Vogel, H.: Late Quaternary palaeoenvironmental reconstruction from Lakes Ohrid and Prespa (Macedonia/Albania border) using stable isotopes, Biogeosciences, 7, 3109-3122, doi:10.5194/bg7-3109-2010, 2010.

Lepš, J. and Šmilauer, P.: Multivariate Analysis of Ecological Data Using CANOCO, Cambridge University Press, Cambridge, UK, 2003.

Levkov, Z. and Williams, D. M.: Fifteen new diatom (Bacillariophyta) species from Lake Ohrid, Macedonia, Phytotaxa, 30, 141, 2011.

Levkov, Z. and Williams, D. M.: Checklist of diatoms (Bacillariophyta) from Lake Ohrid and Lake Prespa (Macedonia), and their watersheds, Phytotaxa, 45, 1-76, 2012.

Levkov, Z., Krstic, S., Metzeltin, D., and Nakov, T.: Diatoms of Lakes Prespa and Ohrid, in: Iconographia Diatomologica Vol. 16, edited by: Lange-Bertalot, H., A.R.G. Gantner Verlag, Ruggell, Liechtenstein, 2007.

Lézine, A. M., von Grafenstein, U., Andersen, N., Belmecheri, S., Bordon, A., Caron, B., Cazet, J. P., Erlenkeuser, H., Fouache, E., Grenier, C., Huntsman-Mapila, P., Hureau-Mazaudier, D., Manelli, D., Mazaud, A., Robert, C., Sulpizio, R., Tiercelin, J. J., Zanchetta, G., and Zeqollari, Z.: Lake Ohrid, Albania, provides an exceptional multi-proxy record of environmental changes during the last glacial-interglacial cycle, Paleogeogr. Paleoecol., 287, 116-127, 2010. 
Lindhorst, K., Krastel, S., Reicherter, K., Stipp, M., Wagner, B., and Schwenk, T.: Sedimentary and tectonic evolution of Lake Ohrid (Macedonia/Albania), Basin Res., 27, 84-101, 2015.

Lorenschat, J., Zhang, X., Anselmetti, F. S., Reed, J. M., Wessels, M., and Schwalb, A.: Recent anthropogenic impact in ancient Lake Ohrid (Macedonia/Albania): a palaeolimnological approach, J. Paleolimnol., 52, 139-154, 2014.

Lotter, A. F., Birks, H. J. B., and Zolitschka, B.: Late-glacial pollen and diatom changes in response to two different environmental perturbations: volcanic eruption and Younger Dryas cooling, J. Paleolimnol., 14, 23-47, 1995.

Mackay, A. W., Jones, V. J., and Battarbee, R. W.: Approaches to Holocene climate reconstruction using diatoms, in: Global Change in the Holocene, edited by: Mackay, A. W., Battarbee, R. W., Birks, H. J. B., and Oldfield, F., Arnold, London, UK, 294-309, 2003.

Mackay, A. W., Edlund, M. B., and Khursevich, G.: Diatoms in ancient lakes, in: The Diatoms: Applications for the Environmental and Earth Sciences, second edition, edited by: Smol, J. P. and Stoermer, E. F., Cambridge University Press, Cambridge, UK, 209-228, 2010.

Marcott, S. A., Shakun, J. D., Clark, P. U., and Mix, A. C.: A reconstruction of regional and global temperature for the past 11300 years, Science, 339, 1198-1201, 2013.

Matter, M., Anselmetti, F. S., Jordanoska, B., Wagner, B., Wessels, M., and Wüest, A.: Carbonate sedimentation and effects of eutrophication observed at the Kališta subaquatic springs in Lake Ohrid (Macedonia), Biogeosciences, 7, 3755-3767, doi:10.5194/bg-7-3755-2010, 2010.

Matzinger, A., Spirkovski, Z., Patceva, S., and Wüest, A.: Sensitivity of ancient Lake Ohrid to local anthropogenic impacts and global warming, J. Great Lakes Res., 32, 158-179, 2006a.

Matzinger, A., Jordanoski, M., Veljanoska-Sarafiloska, E., Sturm, M., Müller, B., and Wüest, A.: Is Lake Prespa jeopardizing the ecosystem of ancient Lake Ohrid?, Hydrobiologia, 553, 89-109, 2006 b.

Matzinger, A., Schmid, M., Veljanoska-Sarafiloska, E., Patceva, S., Guseska, D., Wagner, B., Müller, B., Sturm, M., and Wüest, A.: Eutrophication of ancient Lake Ohrid: Global warming amplifies detrimental effects of increased nutrient inputs, Limnol. Oceanogr., 52, 338-353, 2007.

Mauri, A., Davis, B. A. S., Collins, P. M., and Kaplan, J. O.: The climate of Europe during the Holocene: a gridded pollen-based reconstruction and its multi-proxy evaluation, Quaternary Sci. Rev., 112, 109-127, 2015.

Miho, A. and Lange-Bertalot, H.: Considerations on biodiversity and trophic state of Lake Ohrid (Albanian part) from a microalgae point of view, J. Environ. Prot. Ecol., 4, 543-549, 2003.

Ocevski, B. T. and Allen, H. L.: Limnological studies in a large, deep, oligotrophic lake (Lake Ohrid, Yugoslavia): seasonal and annual primary production dynamics of the pelagial phytoplankton, Arch. Hydrobiol., 79, 429-440, 1977.

Panagiotopoulos, K., Aufgebauer, A., Schäbitz, F., and Wagner, B.: Vegetation and climate history of the Lake Prespa region since the Lateglacial, Quaternary Int., 293, 157-169, 2013.

Petrova, D., Patceva, S., Mitic, V., Shtereva, G., and Gerdzhikov, D.: State of phytoplankton community in the Bulgarian and Macedonian lakes, J. Environ. Prot. Ecol., 9, 501-512, 2008.
Peyron, O., Magny, M., Goring, S., Joannin, S., de Beaulieu, J.L., Brugiapaglia, E., Sadori, L., Garfi, G., Kouli, K., Ioakim, C., and Combourieu-Nebout, N.: Contrasting patterns of climatic changes during the Holocene across the Italian Peninsula reconstructed from pollen data, Clim. Past, 9, 1233-1252, doi:10.5194/cp-9-1233-2013, 2013.

Pross, J., Kotthoff, U., Müller, U. C., Peyron, O., Dormoy, I., Schmiedl, G., Kalaitzidis, S., and Smith, A. M.: Massive perturbation in terrestrial ecosystems of the Eastern Mediterranean region associated with the $8.2 \mathrm{kyr}$ B.P. climatic event, Geology, 37, 887-890, 2009.

Reed, J. M., Cvetkoska, A., Levkov, Z., Vogel, H., and Wagner, B.: The last glacial-interglacial cycle in Lake Ohrid (Macedonia/Albania): testing diatom response to climate, Biogeosciences, 7, 3083-3094, doi:10.5194/bg-7-3083-2010, 2010.

Reicherter, K., Hoffmann, N., Lindhorst, K., Krastel, S., FernándezSteeger, T., Grützner, C., and Wiatr, T.: Active basins and neotectonics: morphotectonics of the Lake Ohrid basin (FYROM and Albania), Z. dt. Ges. Geowiss., 162, 217-234, 2011.

Reimer, P. J., Bard, E., Bayliss, A., Beck, J. W., Blackwell, P. G., Bronk Ramsey, C., Buck, C. E., Cheng, H., Edwards, R. L., Friedrich, M., Grootes, P. M., Guilderson, T. P., Haflidason, H., Hajdas, I., Hatté, C., Heaton, T. J., Hogg, A. G., Hughen, K. A., Kaiser, K. F., Kromer, B., Manning, S. W., Niu, M., Reimer, R. W., Richards, D. A., Scott, E. M., Southon, J. R., Turney, C. S. M., and van der Plicht, J.: IntCal13 and Marine13 radiocarbon age calibration curves $0-50000$ years cal BP, Radiocarbon, 55, 1869-1887, 2013.

Renssen, H., Seppä, H., Crosta, X., Goosse, H., and Roche, D. M.: Global characterization of the Holocene Thermal Maximum, Quaternary Sci. Rev., 48, 7-19, 2012.

Rioual, P. and Mackay, A. W.: A diatom record of centennial resolution for the Kazantsevo Interglacial stage in Lake Baikal (Siberia), Global Planet. Change, 46, 199-219, 2005.

Roberts, N. and Reed, J. M.: Lakes, wetlands, and Holocene environmental change, in: The Physical Geography of the Mediterranean, edited by: Woodward, J. C., Oxford University Press, Oxford, UK, 255-286, 2009.

Roelofs, A. K. and Kilham, P.: The diatom stratigraphy and paleoecology of Lake Ohrid, Yugoslavia, Paleogeogr. Paleoecol., 42, 225-245, 1983.

Rühland, K., Paterson, A. M., and Smol, J. P.: Hemispheric-scale patterns of climate-related shifts in planktonic diatoms from North American and European lakes, Glob. Change Biol., 14, 2740-2754, 2008.

Ryves, D. B., Juggins, S., Fritz, S. C., and Battarbee, R. W.: Experimental diatom dissolution and the quantification of microfossil preservation in sediments, Paleogeogr. Paleoecol., 172, 99-113, 2001.

Saros, J. E. and Anderson, N. J.: The ecology of the planktonic diatom Cyclotella and its implications for global environmental change studies, Biol. Rev., 90, 522-541, 2015.

Saros, J. E., Stone, J. R., Pederson, G. T., Slemmons, K. E. H., Spanbauer, T., Schliep, A., Cahl, D., Williamson, C. E., and Engstrom, D. R.: Climate-induced changes in lake ecosystem structure inferred from coupled neo- and paleoecological approaches, Ecology, 93, 2155-2164, 2012.

Schmidt, R., Kamenik, C., Lange-Bertalot, H., and Klee, R.: Fragilaria and Staurosira (Bacillariophyceae) from sediment surfaces 
of 40 lakes in the Austrian Alps in relation to environmental variables, and their potential for palaeoclimatology, J. Limnol., 63, 171-189, 2004.

Schneider, S. C., Cara, M., Eriksen, T. E., Goreska, B. B., Imeri, A., Kupe, L., Lokoska, T., Patceva, S., Trajanovska, S., Trajanovski, S., Talevska, M., and Sarafiloska, E. V.: Eutrophication impacts littoral biota in Lake Ohrid while water phosphorus concentrations are low, Limnologica, 44, 90-97, 2014.

Shakun, J. D., Clark, P. U., He, F., Marcott, S. A., Mix, A. C., Liu, Z., Otto-Bliesner, B., Schmittner, A., and Bard, E.: Global warming preceded by increasing carbon dioxide concentrations during the last deglaciation, Nature, 484, 49-54, 2012.

Smol, J. P., Wolfe, A. P., Birks, H. J. B., Douglas, M. S. V., Jones, V. V., Korhola, A., Pienitz, R., Rühland, K., Sorvari, S., Antoniades, D., Brooks, S. J., Fallu, M. A., Hughes, M., Keatley, B. E., Laing, T. E., Michelutti, N., Nazarova, L., Nyman, M., Paterson, A. M., Perren, B., Quinlan, R., Rautio, M., Saulnier-Talbot, E., Siitonen, S., Solovieva, N., and Weckström, J.: Climate-driven regime shifts in the biological communities of arctic lakes, P. Natl. Acad. Sci. USA, 102, 4397-4402, 2005.

Stanković, S.: The Balkan Lake Ohrid and Its Living World, in: Monographiae Biologicae Vol. IX, edited by: Bodenheimer, F. S. and Weisbach, W. W., Uitgeverij Dr. W. Junk, Den Haag, The Netherlands, 1960.

Stoermer, E. F., Emmert, G., and Schelske, C. L.: Morphological variation of Stephanodiscus niagarea Ehrenb. (Bacillariophyta) in a Lake Ontario sediment core, J. Paleolimnol., 2, 227-236, 1989.

Stuiver, M. and Reimer, P. J.: Extended ${ }^{14} \mathrm{C}$ data base and revised Calib $3.0{ }^{14} \mathrm{C}$ age calibration program, Radiocarbon, 35, 215230, 1993.

Sulpizio, R., Zanchetta, G., D’Orazio, M., Vogel, H., and Wagner, B.: Tephrostratigraphy and tephrochronology of lakes Ohrid and Prespa, Balkans, Biogeosciences, 7, 3273-3288, doi:10.5194/bg7-3273-2010, 2010.

Tasevska, O., Jersabek, C. D., Kostoski, G., and Gušeska, D.: Differences in rotifer communities in two freshwater bodies of different trophic degree (Lake Ohrid and Lake Dojran, Macedonia), Biologia, 67, 565-572, 2012.

Telford, R. J., Barker, P., Metcalfe, S., and Newton, A.: Lacustrine responses to tephra deposition: examples from Mexico, Quaternary Sci. Rev., 23, 2337-2353, 2004.

Ter Braak, C. J. F.: Ordination, in: Data Analysis in Community and Landscape Ecology, edited by: Jongman, R. H. G., Ter Braak, C. J. F., and van Tongeren, O. F. R., Cambridge University Press, Cambridge, UK, 91-173, 1995.

Ter Braak, C. J. F. and Šmilauer, P.: CANOCO Reference Manual and CanoDraw for Windows User's Guide: Software for Canonical Community Ordination (version 4.5), Microcomputer Power, Ithaca, USA, 2002.
Vogel, H., Wagner, B., Zanchetta, G., Sulpizio, R., and Rosén, P.: A paleoclimate record with tephrochronological age control for the last glacial-interglacial cycle from Lake Ohrid, Albania and Macedonia, J. Paleolimnol., 44, 295-310, 2010.

Wagner, B., Lotter, A. F., Nowaczyk, N., Reed, J. M., Schwalb, A., Suipizio, R., Valsecchi, V., Wessels, M., and Zanchetta, G.: A 40000 -year record of environmental change from ancient Lake Ohrid (Albania and Macedonia), J. Paleolimnol., 41, 407-430, 2009.

Wagner, B., Vogel, H., Zanchetta, G., and Sulpizio, R.: Environmental change within the Balkan region during the past ca. $50 \mathrm{ka}$ recorded in the sediments from lakes Prespa and Ohrid, Biogeosciences, 7, 3187-3198, doi:10.5194/bg-7-3187-2010, 2010.

Wagner, B., Francke, A., Sulpizio, R., Zanchetta, G., Lindhorst, K., Krastel, S., Vogel, H., Rethemeyer, J., Daut, G., Grazhdani, A., Lushaj, B., and Trajanovski, S.: Possible earthquake trigger for 6th century mass wasting deposit at Lake Ohrid (Macedonia/Albania), Clim. Past, 8, 2069-2078, doi:10.5194/cp-8-20692012, 2012.

Wagner, B., Wilke, T., Krastel, S., Zanchetta, G., Sulpizio, R., Reicherter, K., Leng, M. J., Grazhdani, A., Trajanovski, S., Francke, A., Lindhorst, K., Levkov, Z., Cvetkoska, A., Reed, J. M., Zhang, X., Lacey, J. H., Wonik, T., Baumgarten, H., and Vogel, H.: The SCOPSCO drilling project recovers more than 1.2 million years of history from Lake Ohrid, Sci. Dril., 17, 19-29, doi:10.5194/sd-17-19-2014, 2014.

Watzin, M. C., Puka, V., and Naumoski, T. B.: Lake Ohrid and Its Watershed: State of the Environment Report, Lake Ohrid Conservation Project, Tirana, Albania and Ohrid, Macedonia, 2002.

Wilson, G. P., Reed, J. M., Lawson, I. T., Frogley, M. R., Preece, R. C., and Tzedakis, P. C.: Diatom response to the Last GlacialInterglacial Transition in the Ioannina basin, northwest Greece: implications for Mediterranean palaeoclimate reconstruction, Quaternary Sci. Rev., 27, 428-440, 2008.

Winder, M., Reuter, J. E., and Schladow, S. G.: Lake warming favours small-sized planktonic diatom species, Proc. R. Soc. BBiol. Sci., 276, 427-435, 2009.

Zhang, X., Reed, J., Wagner, B., Francke, A., and Levkov, Z.: Lateglacial and Holocene climate and environmental change in the northeastern Mediterranean region: diatom evidence from Lake Dojran (Republic of Macedonia/Greece), Quaternary Sci. Rev., 103, 51-66, 2014. 